In this context the non-esterified fatty acid levels are of considerable interest. The afternoon fasting levels were almost always significantly higher than those in the morning, confirming the observations of Carroll and Nestel (1973), who compared values at 07.00 and 19.00 hours. Non-esterified fatty acids have been shown to be insulin antagonists in that their metabolism impairs glucose uptake by muscle (Randle et al., 1963; Seyffert and Madison, 1967). Baker and Mottram (1973), have reported a reduced uptake of glucose by human forearm muscles in the afternoon. Possibly increased lipolysis causing raised plasma non-esterified fatty acid levels and a consequent increase in their metabolism by muscle might be responsible for this phenomenon. Studies of forearm tissues during glucose tolerance tests have shown that glucose uptake is greater in lean than in obese subjects (Butterfield et al., 1967; Whichelow and Butterfield, 1971). Thus a change in peripheral glucose uptake due to a change in insulin sensitivity, whether or not induced by nonesterified fatty acids, might be expected to affect blood sugar levels more in the lean than in the obese, which conforms with the observations in the present study and with those of Jarrett and Keen (1970), Gibson and Jarrett (1972), and Oakley et al. (1973). The reason for the higher afternoon level of nonesterified fatty acid is unknown, but from the observations of Carroll and Nestel (1973) and Stimmler et al. (1973) it seems unlikely that exercise can be held solely responsible.

We are indebted to all those who volunteered as subjects for this investigation. Facilities were kindly made available in the medical department of the Greater London Council and we are grateful to Drs. A. B. Stewart, G. Wigley, and T. Hall, and to Mr. R. C. Coulter of the medical department for their help in making the study possible. Mr. K. Kilbourn and Mr. P. Rutland provided able technical help. P.Z.Z. wishes to thank the British Insulin Manufacturers for their financial support.

\section{References}

Baker, P. G. B., and Mottram, R. F. (1973). Clinical Science, 44, 479. Bowen, A. J., and Reeves, R. L. (1967). Archives of Internal Medicine, 119, 261 .

Butterfield, W. J. H., Abrams, M. E., St. John, D. J. B., and Whichelow, M. J. (1967). Metabolism, 16, 19 .

Carroll, K. F., and Nestel, P. J. (1973). Diabetes, 22, 333.

Carruthers, M., and Young, D. A. B. (1973). In Automation in Analytical Chemistry, ed. L. T. Skeegs. In press.

Gibson, T., and Jarrett, R. J. (1972). Lancet, 2, 947.

Jarrett, R. J., and Keen, H. (1969). British Medical fournal, 2, 341.

Jarrett, R. J., and Keen, H. (1970). British Medical fournal, 4, 334.

Jarrett, R. J., Baker, I. A., Keen, H., and Oakley, N. W. (1972). British Medical fournal, 1, 199.

Keys, A., Fidanza, F., Karvonen, M. J., Kimura, N., and Taylor, H. L. (1972). Fournal of Chronic Diseases, 25, 329.

Oakley, N. W., Monier, D., and Wynn, V. (1973). Diabetologia, 9, 235.

Randle, P. J., Garland, P. B., Hales, C. N., and Newsholme, E. A. (1963). Lancet, 1, 785.

Roberts, H. J. (1964). Fournal of the American Geriatrics Society, 12, 423.

Seyffert, W. A., Jr., and Madison, L. L. (1967). Diabetes, 16, 765.

Stimmler, L., Gibson, T., Shiu, M., Jarrett, R. J., and Rutland, P. (1973) Paper presented to the Autumn Meeting of the Medical and Scientific Section of the British Diabetic Association.

Whichelow, M. J., and Butterfield, W. J. H. (1971). Quarterly fournal of Medicine, 40, 261.

\title{
Diurnal Variation in Response to Intravenous Glucose*
}

\author{
MARGARET J. WHICHELOW, \\ SUSAN GRAINGER \\ R. A. STURGE, \\ H. KEEN, \\ R. J. JARRETT, \\ L. STIMMLER,
}

British Medical fournal, 1974, 1, 488-491

\section{Summary}

Intravenous glucose tolerance tests $(25 \mathrm{~g})$ were performed in the morning and afternoon on 13 apparently normal persons. The individual $\mathbf{K}$ values (rate of decline of blood sugar) were all higher in the morning tests, and the mean values were significantly higher in the morning. Fasting blood sugar levels were slightly lower in the afternoon. There was no difference between the fasting morning and afternoon plasma insulin levels, but the levels after glucose were lower in the afternoon. Growth hormone levels were low at all times in nonapprehensive subjects and unaffected by glucose. The results suggest that the impaired afternoon intravenous glucose tolerance, like oral glucose tolerance, is associated with impaired insulin release and insulin resistance.

*Paper presented at the 8th Congress of the International Diabetes Federation, Brussels, July 1973.

\section{Introduction}

Various groups of workers (Roberts, 1964; Bowen and Reeves, 1967; Jarrett and Keen, 1969) have established that in nondiabetic subjects the curve of glycaemia after oral glucose is higher in the afternoon than in the morning and that the relative glucose intolerance in the afternoon is associated with a delayed and lower insulin response (Jarrett et al., 1972; Carroll and Nestel, 1973; Oakley et al., 1973). Gibson and Jarrett (1972), however, have also shown that after the intravenous injection of insulin blood sugar depression is also less in the afternoon. Thus two factors-diminished insulin release and increased resistance to the peripheral effects of insulin-may be responsible for the afternoon intolerance.

Insulin release after oral gluoose is influenced by intestinal factors such as differing absorption rates and the release of gut hormones, and these might, in part, be responsible for diurnal differences in glucose tolerance. To investigate the possible role of intestinal factors we have compared the response to intravenous glucose in the morning and afternoon in nondiabetic subjects.

\section{Subjects and Methods}

Details of the 13 subjects ( 7 men and 6 women) who successfully completed both the morning and afternoon tests are given in table I. The group was composed mostly of hospital staff but also included patients convalescing from various onthopaedic disorders. None of the subjects was obese and none had any prior clinical or biochemical evidence of diabetes mellitus or other metabolic disturbance. 
TABLE I-Details of Subjects Studied

\begin{tabular}{|c|c|c|c|c|c|}
\hline \multirow[t]{2}{*}{$\begin{array}{l}\text { Subject } \\
\text { No. }\end{array}$} & \multirow[t]{2}{*}{ Sex } & \multirow[t]{2}{*}{$\begin{array}{c}\text { Age } \\
\text { (Years) }\end{array}$} & \multicolumn{2}{|c|}{$\begin{array}{c}\text { Fasting Blood Sugar } \\
(\mathrm{mg} / 100 \mathrm{ml})\end{array}$} & \multirow[t]{2}{*}{ Diagnosis on Admission } \\
\hline & & & a.m. & p.m. & \\
\hline $\begin{array}{r}1 \\
2 \\
3 \\
4 \\
5 \\
6 \\
7 \\
8 \\
9 \\
10 \\
11 \\
12 \\
13\end{array}$ & $\begin{array}{l}\text { M. } \\
M . \\
M . \\
M . \\
M . \\
M . \\
M . \\
\text { F. } \\
\text { F. } \\
\text { F. } \\
\text { F. } \\
\text { F. } \\
\text { F. }\end{array}$ & $\begin{array}{l}61 \\
64 \\
26 \\
35 \\
32 \\
25 \\
47 \\
24 \\
24 \\
50 \\
30 \\
35 \\
37\end{array}$ & $\begin{array}{l}82 \\
93 \\
76 \\
87 \\
81 \\
92 \\
99 \\
95 \\
95 \\
89 \\
82 \\
82 \\
88\end{array}$ & $\begin{array}{l}85 \\
84 \\
72 \\
84 \\
76 \\
80 \\
97 \\
76 \\
85 \\
88 \\
84 \\
72 \\
78\end{array}$ & $\begin{array}{l}\text { Hiatus hernia, arthritis } \\
\text { Bronchitis } \\
\text { Dislocation of knee cartilage } \\
\text { Prolapsed disc } \\
\text { Healthy } \\
\text { ", } \\
\text { ", } \\
\text { " } \\
\text { ", } \\
\text {,: }\end{array}$ \\
\hline
\end{tabular}

Each subject had two tests, one beginning at 9 a.m. and the other at 3 p.m. They were performed in random order and were usually one week apart. Each test was preceded by a nine-hour fast which followed a standard meal of about $50 \mathrm{~g}$ carbohydrate taken as jam sandwiches. After that only water was allowed until the end of the test.

To facilitate repeated blood sampling a fine polyethylene catheter was inserted into an antecubital vein and kept patent between blood sampling by the slow infusion of saline. Two fasting blood samples were taken immediately before the intravenous infusion of $25 \mathrm{~g}$ glucose, as a $50 \%$ solution, into the opposite arm. The next sample was taken at the end of the infusion (three minutes) and then at five minutes from zero time. Further samples were taken at five-minute intervals for 30 minutes and then at 10-minute intervals for up to 60 minutes. Blood sugar, plasma insulin, and plasma growth hormone were measured in each sample and non-esterified fatty acids in the fasting samples.

Blood sugar levels were measured using the ferricyanide reduction method on the Autoanalyzer (Technicon method $\mathrm{N}-9 \mathrm{a})$ and plasma insulin and growth hormone levels by immunoassay using a double antibody precipitation method. Plasma non-esterified fatty acids were measured by the semiautomated method of Carruthers and Young (1973). The K value (rate of decline of blood sugar) was calculated in each test from the twentieth to the sixtieth minute.

\section{Results}

In every case the $\mathrm{K}$ value was highly significantly lower in the afternoon than in the morning $(P<0.001)$ (table II). The fasting blood sugar levels were slightly $(P<0.05)$ lower in the afternoon than in the morning (table I). The mean blood sugar curves for the two tests (fig. 1) showed no difference in the height or timing of the peak level but the rate of fall after the peak was much greater in the morning.

The mean insulin values were plotted in the same way (fig. 2). There was no difference in the fasting or peak levels or in the timing of the peak between the morning and after-

TABLE II-K Values calculated from Blood Sugar Levels between 20 and 60 Minutes

\begin{tabular}{|c|c|c|c|c|c|}
\hline \multicolumn{3}{|c|}{ Men } & \multicolumn{3}{|c|}{ Women } \\
\hline $\begin{array}{c}\text { Subject } \\
\text { No. }\end{array}$ & a.m. & p.m. & $\begin{array}{l}\text { Subject } \\
\text { No. }\end{array}$ & a.m. & p.m \\
\hline $\begin{array}{l}1 \\
2 \\
3 \\
4 \\
5 \\
6 \\
7\end{array}$ & $\begin{array}{l}1.74 \\
1.49 \\
1.61 \\
1.83 \\
2.43 \\
1.75 \\
1.85\end{array}$ & $\begin{array}{l}0.95 \\
0.74 \\
1.01 \\
1.13 \\
1.40 \\
1.65 \\
1.04\end{array}$ & $\begin{array}{r}8 \\
9 \\
10 \\
11 \\
12 \\
13\end{array}$ & $\begin{array}{l}2.02 \\
1.49 \\
1.26 \\
1.49 \\
3.47 \\
2.35\end{array}$ & $\begin{array}{l}1.09 \\
1.11 \\
0.94 \\
1.01 \\
2.27 \\
1.06\end{array}$ \\
\hline Mean & 1.81 & $1 \cdot 13$ & Mean & 2.01 & 1.25 \\
\hline
\end{tabular}

Significance of difference between morning and afternoon values : $t=7.51 ; \mathrm{P}<0.001$.

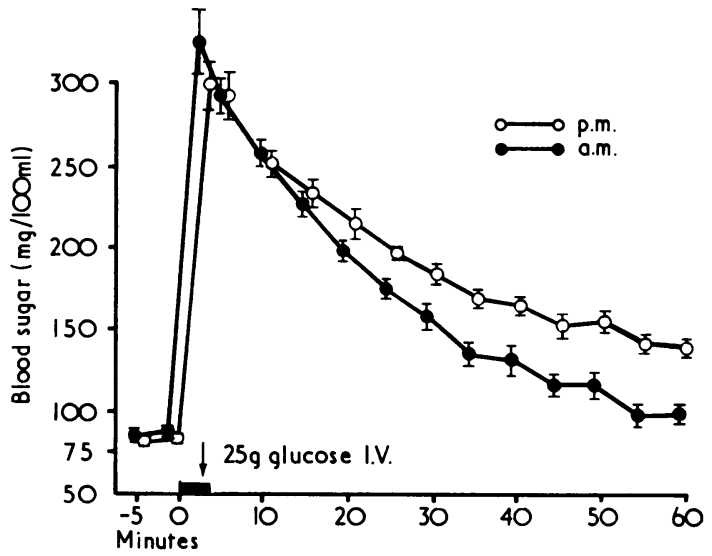

FIG. 1-Blood sugar levels (mean \pm S.E. of mean) during morning and afternoon tests.

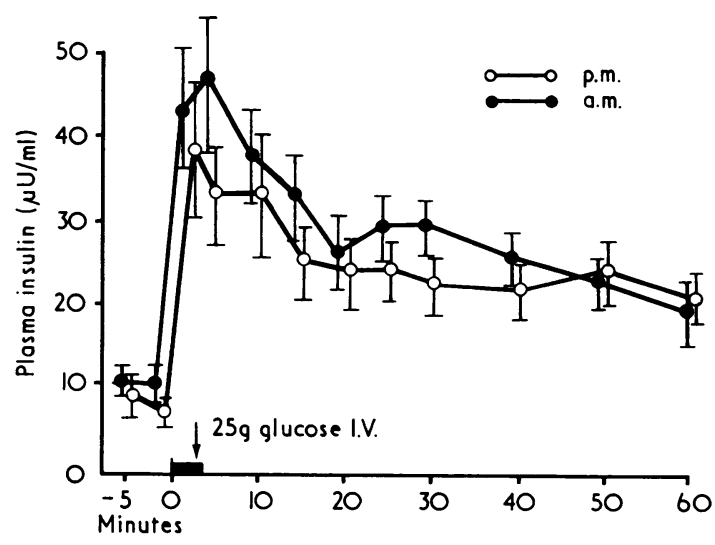

FIG. 2-Plasma insulin levels (mean \pm S.E. of mean) during morning and afternoon tests.

noon tests. After the administration of glucose, however, the mean levels of insulin were slightly lower in the afternoon. When the mean individual post-glucose insulin values were compared (table III) the afternoon values were found to be significantly lower $(P<0.05)$.

TABLE III-Mean Insulin Levels $(\mu \mathrm{U} / \mathrm{ml})$ when Fasting and after Glucose

\begin{tabular}{|c|c|c|c|c|}
\hline \multirow{2}{*}{$\begin{array}{c}\text { Subject } \\
\text { No. }\end{array}$} & \multicolumn{2}{|c|}{ a.m. } & \multicolumn{2}{|c|}{ p.m. } \\
\hline & Fasting & $\begin{array}{l}\text { After } \\
\text { Glucose }\end{array}$ & Fasting & $\begin{array}{l}\text { After } \\
\text { Glucose }\end{array}$ \\
\hline $\begin{array}{r}1 \\
2 \\
3 \\
4 \\
5 \\
6 \\
7 \\
8 \\
9 \\
10 \\
11 \\
12 \\
13\end{array}$ & $\begin{array}{r}11 \\
16 \\
13 \\
7 \\
23 \\
15 \\
3 \\
17 \\
5 \\
14 \\
3 \\
6 \\
4\end{array}$ & $\begin{array}{l}42 \\
31 \\
23 \\
26 \\
70 \\
37 \\
25 \\
40 \\
29 \\
35 \\
14 \\
27 \\
12\end{array}$ & $\begin{array}{r}4 \\
12 \\
4 \\
2 \\
17 \\
9 \\
6 \\
28 \\
3 \\
14 \\
2 \\
4 \\
2\end{array}$ & $\begin{array}{r}44 \\
24 \\
18 \\
13 \\
62 \\
30 \\
42 \\
32 \\
20 \\
30 \\
14 \\
24 \\
9\end{array}$ \\
\hline
\end{tabular}

Significance of difference between post-glucose morning and afternoon values: $t=1.97 ; \mathrm{P}<0.05$.

The mean of the two fasting plasma growth hormone levels and the mean levels after glucose for the morning and afternoon tests are shown in fig. 3. In most subjects the levels were low (below $5 \mu \mathrm{U} / \mathrm{ml}$ ) in the fasting state at both times 
of the day and were unaffected by glucose administration. A few subjects were apprehensive during one or other test and these had the highest growth hormone levels. There appeared, however, to be no correlation between these higher levels and the $K$ values or the diurnal variation in $K$ value. Fasting non-esterified fatty acids were significantly higher in the afternoon (506.9 $\pm 57.0 \mu \mathrm{Eq} / 1$. compared with $330.1 \pm$ $45 \cdot 8 \mu \mathrm{Eq} / 1$.$) .$
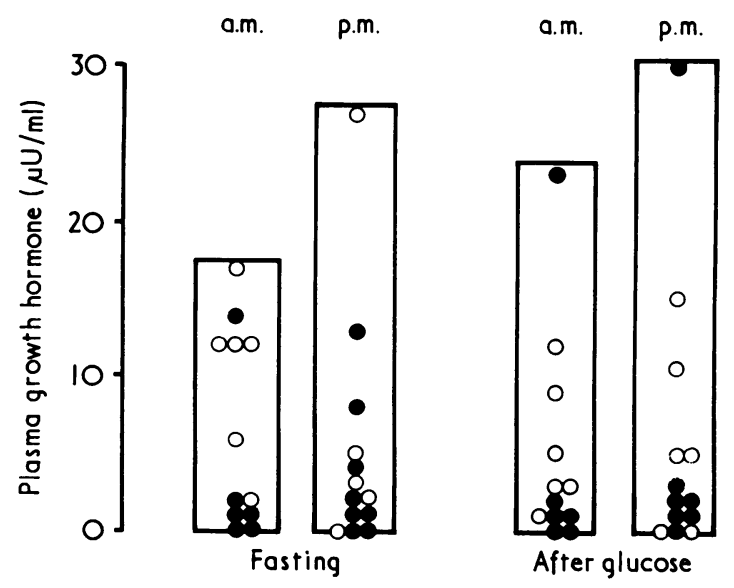

FIG. 3-Mean growth hormone levels during morning and afternoon tests. $=$ Men. $\mathrm{O}=$ Women.

There were no complications of the test such as pyrexia or thrombosis at the site of the glucose injection. Nevertheless, on close questioning most subjects reported some mildly unpleasant or disturbing sensations during the injection. The most common was aching in the upper arm or axilla (9 tests), which was quite severe in some cases. Some subjects experienced a transient sensation of heat throughout the body ( 7 tests) and some became apprehensive during the injection (6 tests). The sudden onset of thirst (4 tests) was presumably due to the rapid change in osmolarity in the blood as the sugar level rose.

\section{Discussion}

Our finding of a diurnal variation in intravenous glucose tolerance confirms the reponts, in abstract, of Abrams et al. (1968) and Németh et al. (1970) and one (Carroll and Nestel, 1973) which appeared during the preparation of this paper. Abrams et al. and Németh et al. obtained results similar to ours though their tests were carried out in sequence during the same day. Carroll and Nestel (1973) compared two tests, on separate days, performed at 7 a.m. and 7 p.m. The 11 men tested all had lower $K$ values in the evening tests. Though these combined results do not entirely exclude an intestinal role in the diurnal variation in oral glucose tolerance they do suggest that any such influence is of small degree. The evidence, in fact, suggests that more than one factor is involved in the afternoon hyperglycaemia. Insulin levels are lower in the afternoon after glucose loading in both intravenous and oral tests, suggesting that insulin release is impaired. This was also observed by Baker and Jarrett (1972) using a different insulinogenic stimulus, tolbutamide.

Apart from impaired insulin release in the latter part of the day it seems likely that there is also a diurnal variation in the hypoglycaemic response to insulin. This was suggested by the relative constancy of the diurnal blood sugar change but the poor individual correlation with the behaviour of the plasma insulin (Jarrett et al., 1972). It was supponted by the observations of Gibson and Jarrett (1972) that the intravnous administration of insulin 0.05 to $0.1 \mathrm{unit} / \mathrm{kg}$ to non-diabetic subjects produced a smaller hypoglycaemic effect in the afternoon. In the present study the small variation in insulin levels from the morning to the afternoon, with a large difference in the glucose levels, also suggested that changes in endogenous insulin sensitivity play a part in the causation of the afternoon glucose intolerance.

The site of afternoon insulin resistance in the body cannot, of course, be determined from studies such as these. Evidence from other work, however, suggests that the peripheral tissues may be involved. Baker and Mottram (1973) found diminished arteriovenous glucose differences across the forearm in fasting subjects in the afternoon compared with the morning, suggesting a smaller uptake of glucose. Studies of the forearm tissues during intravenous and oral glucose tolerance tests have shown that glucose uptake was high in lean subjects and very low in obese subjects (Butterfield et al., 1967; Whichelow and Butterfield, 1971). In conjunction with this, Jarrett and Keen (1970) reported that the diurnal variation in oral glucose tolerance was much less in obese than lean subjects, an observation confirmed by Oakley et al. (1973). Changes in peripheral glucose uptake secondary to changes in insulin sensitivity would presumably be more likely to alter blood sugar levels in lean subjects than in obese ones.

The cause of the impaired insulin release and insulin resistance in the latter part of the day is difficult to determine. It does not appear to be related to circulating growth hormone levels since these were unaffected by the time of the day or the administration of glucose. Plasma contisol levels were not measured but it is established that these are higher in the morning. Cortisol is a well known hyperglycaemic agent but it is difficult to see any association with the changes in glucose tolerance, which worsens as the circulating cortisol levels fall. In this context it is interesting that mean fasting nonesterified fatty acid levels were significantly higher in the afternoon, a phenomenon also observed by Carroll and Nestel (1973) and Zimmet et al. (1974). As increased nonesterified fatty acid metabolism by muscle tissue causes some degree of "insulin resistance" (Randle et al., 1963) this might contribute to if not be entirely responsible for the diurnal change in insulin sensitivity.

Intravenous glucose tolerance tests were carried out on a large series of subjects by Duncan (1956) and Lundbaek (1962). Both workers give a range of "normal" and "diabetic" $K$ values which were closely similar and suggested that a $K$ value of 0.97 was the lower limit of normality. In our series, though all the morning $K$ values lay well above 0.97 three subjects had afternoon values below 0.97 and might, therefore, be classified as diabetic (table II). Interestingly, in a study using the oral test Jarrett and Keen (1970) found a similar proportion ( $25 \%$ ) of subjects who had been "normal" in the morning but who had become "diabetic" (that is, had a peak blood sugar exceeding $180 \mathrm{mg} / 100 \mathrm{ml}$ and a two-hour blood sugar above $120 \mathrm{mg} / 100 \mathrm{ml}$ ) in the afternoon.

The occurrence of frequent mild but neventheless disturbing side effects-ache in the arm, sensation of heat, apprehension, and thirst-with the intravenous test, which are not seen with the oral test, throw doubt on the idea that the intravenous test should be employed widely. Also since diurnal variations occur in the blood sugar and plasma insulin levels with this test as well as with the oral test there is no advantage to be gained by attempting to use it as a screening test throughout the day in population surveys.

We are grateful to the volunteers who participated in this study. Mr. K. Kilbourn and Mr. P. Rutland provided excellent technical help. 


\section{References}

Abrams, R. L., Cerchio, G. M., and Graber, A. L. (1968). Diabetes, 17, 314. Baker, I. A., and Jarrett, R. J. (1972). Lancet, 2, 945.

Baker, P. G. B., and Mottram, R. F. (1973). Clinical Science, 44, 479.

Bowen, A. J., and Reeves, R. L. (1967). Archives of Internal Medicine, 119, 261 .

Butterfield, W. J. H., Abrams, M. E., St. John, D. J. B., and Whichelow, M. J. (1967). Metabolism, 16, 19.

Carroll, K. F., and Nestel, P. J. (1973). Diabetes, 22, 333.

Carruthers, M., and Young, D. A. B. (1973). In Automation in Analytical Chemistry, ed. L. T. Skeegs. In press.

Duncan, L. J. P. (1956). Quarterly Fournal of Experimental Medicine, 41, 85. Gibson, T., and Jarrett, R. J. (1972). Lancet, 2, 947.
Jarrett, R. J., and Keen, H. (1969). British Medical fournal, 2, 341.

Jarrett, R. J., and Keen, H. (1970). British Medical foutnal, 4, 334

Jarrett, R. J., Baker, I. A., Keen, H., and Oakley, N. W. (1972). British Medical fournal, $1,199$.

undbaek, K. (1962). British Medical fournal, 1, 1507.

Nemeth, S., Vigas, M., Macho, L., and Stukovsky, R. (1970). Diabetologia, 6, 641.

Oakley, N. W., Monier, D., and Wynn, V. (1973). Diabetologia, 9, 235.

Randle, P. J., Garland, P. B., Hales, C. N., and Newsholme, E. A. (1963). Lancet, $1,785$.

Roberts, H. J. (1964). Fournal of the American Geriatrics Society, 12, 423.

Whichelow, M. J., and Butterfield, W. J. H. (1971). Quarterly fournal of Medicine, 40, 261 .

Zimmet, P. Z., Wall, J. R., Rome, R., Stimmler, L., and Jarrett, R. J. (1974). British Medical fournal. In press.

\title{
Aspirin and Anaemia in Childhood
}

\author{
H. HEGGARTY
}

British Medical fournal, 1974, 1, 491-492

\section{Summary}

Chronic aspirin ingestion in childhood is not uncommon, often goes undetected, and may cause serious anaemia from occult blood loss. Five cases are described.

\section{Introduction}

Acute aspirin poisoning is an emergency in paediatric practice but the dangers of chronic aspirin ingestion by children are not sufficiently recognized. Marshall and Kuzemko (1972) drew attention to aspirin-induced haematemesis in three children. This paper describes five children in whom significant anaemia seemed clearly related to chronic aspirin ingestion.

\section{Case Reports}

Case 1.-A 3-year-old boy was admitted to hospital because of pallor of three weeks' duration. His dietary intake had been normal, there was no history of blood loss, and drug ingestion was denied by the parents. Only pallor was found on examination. Haemoglobin was $5.2 \mathrm{~g} / 100 \mathrm{ml}$ and the blood showed an iron deficiency pattern. The results of extensive investigations, including coagulation studies, faecal fat analysis, and barium studies, were normal. Faecal occult blood tests gave positive results for the first four days. The anaemia responded promptly to iron therapy. On followup at outpatient clinics repeated history taking showed that for over six months before admission the boy had been taking one "junior" 150-mg aspirin tablet nightly as a sedative, prescribed by his family doctor, plus two such tablets daily if "unwell in any way." Thereafter he stopped taking aspirin, he remained well, and anaemia did not recur over a two-year follow-up period.

Case 2.-A 3-year-old boy was admitted to hospital with a sixweek history of progressive pallor. His diet was normal and his parents denied any history of bleeding or drug ingestion. Pallor was the only abnormal clinical finding. Haemoglobin was 4.3 $\mathrm{g} / 100 \mathrm{ml}$ and the blood film showed an iron-deficiency pattern. The results of stool occult blood tests were positive on the first three days after admission but negative thereafter. Barium studies showed nothing abnormal in the gastrointestinal tract. Malabsorption and coagulation defects were excluded. The anaemia responded

Friarage Hospital, Northallerton DL6 1JG

H. HEGGARTY, M.B., M.R.C.P., Consultant Paediatrician to iron therapy and did not recur over a three-year follow-up period. From repeated history taking it emerged that the boy had been taking two or three $300-\mathrm{mg}$ aspirin tablets daily for many months administered as a "sedative" by a relative.

Case 3.-A 14-year-old boy was admitted to hospital with a sixmonth history of listlessness, pallor, and dyspnoea on effort. He had fainted three times during the previous two weeks. He denied drug ingestion. Pallor and koilonychia were the only abnormal physical signs. Haemoglobin was $5.8 \mathrm{~g} / 100 \mathrm{ml}$ and the blood film was classcial of iron deficiency. The results of faecal occult blood tests were positive for the first five days. Haemolysis and coagulation deficits were excluded. The anaemia responded promptly and permanently to iron therapy. After repeated questioning the boy disclosed that he had been taking $600 \mathrm{mg}$ of aspirin daily and often $600 \mathrm{mg}$ at night also for over six months "to relieve mild toothaches, headaches, and sleeplessness."

Case 4.-The patient was a 12-year-old girl who complained of recurrent abdominal pain and headaches for four months. Her diet was normal and drug ingestion was denied. The only abnormal physical finding was pallor. Haemoglobin was $7.1 \mathrm{~g} / 100 \mathrm{ml}$ and a blood film showed iron deficiency. Initial results of stool occult blood tests were positive. Studies of coagulation and absorption showed these to be normal. The gastrointestinal tract appeared normal on barium radiography. The anaemia responded to iron therapy and did not recur over a two-year follow-up period. Her original symptoms also disappeared. At her third follow-up attendance she admitted having taken $600-1,200 \mathrm{mg}$ of aspirin daily for four months before her admission to hospital.

Case 5.-The patient was an 8-month-old infant who was noted to be pale at a routine clinical examination. The parents had not been concerned. Birth, dietary, and developmental histories were normal. The parents denied any drug ingestion. Apart from pallor there were no clinical findings. Haemoglobin was $7.4 \mathrm{~g} / 100 \mathrm{ml}$ and the blood film showed iron deficiency. Stool occult blood tests gave positive results, but the results of detailed haematological tests were normal. On closer questioning the parents admitted that the baby had received two "junior" $150-\mathrm{mg}$ aspirin tablets daily for the previous six to eight weeks for febrile episodes, teething, and as a sedative. Aspirin was stopped, the anaemia responded to iron therapy, and the baby remained well over a six-month follow-up period.

\section{Discussion}

The diagnosis of chronic bleeding from the gastrointestinal tract induced by aspirin ingestion can be made only empirically. The similar clinical patterns in the five children, the absence of other explanations despite thorough investigation, and the complete recoveries when aspirin was stopped suggest that the drug ingestion caused the anaemia. The bleeding may be alarmingly obvious (Marshall and Kuzemko, 1972) but was occult in the group of children described above. The value of a careful history needs to be re-emphasized. Patients 